\title{
Methylene blue improves hemodynamic shock but increases lipoperoxidation in severe acute pancreatitis pig model $^{1}$
}

\author{
Azul de metileno melhora as condições hemodinâmicas do choque circulatório, mas \\ aumenta a peroxidação lipídica em um modelo suino de pancreatite aguda grave
}

\author{
Roberto Ferreira Meirelles Jr ${ }^{\mathrm{I}}$, Reginaldo Ceneviva ${ }^{\text {II }}$, Fernanda Viaro ${ }^{\text {III }}$, Caroline Floreoto Baldo ${ }^{\text {IV }}$, Paulo Roberto \\ Barbosa Evorav $^{\text {v }}$ \\ I Fellow Phd degree, Department of Surgery and Anatomy, Ribeirão Preto Faculty of Medicine, University of São Paulo, SP, Brazil. \\ ${ }^{\text {II }}$ Full Professor, Department of Surgery and Anatomy, Ribeirão Preto Faculty of Medicine, University of São Paulo, SP, Brazil.

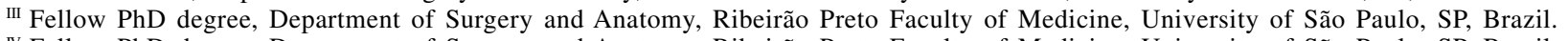 \\ Iv Fellow PhD degree, Department of Surgery and Anatomy, Ribeirão Preto Faculty of Medicine, University of São Paulo, SP, Brazil. \\ v Full Professor and Head, Division Thoracic and Cardiovascular Surgery, Department of Surgery and Anatomy, Ribeirão Preto Faculty \\ of Medicine, University of São Paulo, Brazil.
}

\begin{abstract}
Purpose: Study hemodynamic pattern and lipoperoxidation during methylene blue (MB) treatment on taurocholate enterokinase induced acute pancreatitis (AP). Methods: Thirty pigs were equally divided in control group; MB group; AP group; MB previous AP group; and MB after 90 min of induced AP group. MB was given iv in a bolus dose (2mg.kg-1) followed by maintenance dose (2 mg.kg-1.h-1). Hemodynamic parameters were recorded continuously during $180 \mathrm{~min}$ by Swan-Ganz catheter. Blood samples were taken every $60 \mathrm{~min}$ to determine arterial and venous nitrate, malondialdehyde (MDA) and amylase. Pancreatic tissue was removed for histopathologic study. Results: In AP group MBP and CO decreased over time $33 \%(\mathrm{p}<0.05)$ and $52 \%(\mathrm{p}<0.05)$, respectively. In MB previous induced-AP group, there was 70 minutes delay $(\mathrm{p}<0.05)$ to decrease MBP and CO. In MB group arterial and venous nitrite decreased $(\mathrm{p}<0.05)$ over time. MB infusion increased ( $\mathrm{p}>0.05$ ) serum MDA when associated to AP. After induced AP, MB did not reverse MBP and CO decrease. There was no difference in serum amylase and necro-hemorrhagic findings with MB treatment. Conclusions: In this taurocholate-induced AP model MB treatment delayed hemodynamic shock and decreases serum nitrate levels but increases serum MDA levels. No volemic replacement was done and it may have been a mitigated factor to a poor tissue perfusion and impairment microcirculation. Further investigations are needed to elucidate MB treatment role during AP treatment.
\end{abstract}

Key words: Acute Pancreatitis. Methylene Blue. Nitric Oxide. Shock. Lipoperoxidation. Taurocholate.

\section{RESUMO}

Objetivo: estudar o perfil hemodinâmico e a lipoperoxidação durante o tratamento com azul de metileno (AM) de pancreatite aguda (PA) induzida por taurocolato-enteroquinase. Métodos: Trinta porcos foram igualmente divididos em: grupo controle, grupo AM; grupo PA; grupo AM prévio à PA; grupo AM após 90 minutos após a indução da PA. O AM foi administrado sob a forma de bolus EV (2mg.kg-1) seguido por dose de manutenção (2 mg.kg-1.h-1). Os parâmetros hemodinâmicos foram registrados continuamente durante $180 \mathrm{~min}$ com auxílio de cateter de Swan-Ganz. Amostras sanguíneas foram colhidas a cada 60 min para a determinação arterial e venosa de nitrato, malondialdeido (MDA) and amilase. Removeu-se tecido pancreático para estudo histopatológico. Resultados: No grupo PA a pressão arterial media (PAM) e o débito cardíaco (DC) diminuíram respectivamente $33 \%(\mathrm{p}<0.05)$ e $52 \%(\mathrm{p}<0.05)$ no decorrer do tempo. No grupo AM prévio à indução da PA ocorreu 70 minutes de demora $(\mathrm{p}<0.05)$ para as diminuições da PAM e DC. No grupo AM houve diminuição temporal do nitrato arterial e venoso $(\mathrm{p}<0.05)$. A infusão de AM aumentou os valores de MDA sérico quando associado a PA ( $>>0.05)$. Após a indução da PA a infusão de AM não reverteu as quedas da PA e DC. Não houve diferenças nos níveis de amilase sérica e achados histológicos com o tratamento com o azul de metileno. Conclusões: No presente modelo de PA induzida por taurocolato o AM retardou o desenvolvimento do choque circulatório, diminuiu os níveis de nitrato mas aumentou os níveis de MDA. Não se realizou nenhum tipo de reposição volêmica que poderia melhorar a perfusão tecidual e melhora da microcirculação. Investigações adicionais são necessárias para elucidar o papel terapêutico do AM no tratamento da PA aguda.

Descritores: Pancreatite Aguda. Azul de Metileno. Óxido Nítrico. Choque Circulatório. Lipoperoxidação. Taurocolato.

1. Research performed at Department of Surgery and Anatomy, Ribeirão Preto Faculty of Medicine, University of São Paulo, SP, Brazil. 


\section{Introduction}

The nitric oxide $(\mathrm{NO})$ role in acute pancreatitis (AP) pathogenesis remains controversial ${ }^{1}$ with some studies suggesting that it potentiates the oxidative stress and pancreatic parenchyma injury, ${ }^{2,3}$ while others report that it reduces the pancreatic dysfunction by increasing pancreatic blood flow in response to NO releasing by endothelial cells. ${ }^{4-7}$

NO is synthesized from L-arginine by action of a single enzyme, oxide nitric synthase (NOS). NO action can be blocked by methylene blue (MB), a GMPc inhibitor., ${ }^{8,9}$ MB blocks GMP-c increase, the ultimate effector pathway of NO production with vasodilatation action. MB also may inhibit the NO synthesis.

MB clinical use has been reported in sepses, renal and hepatic transplantation, anaphylactic shock and shock associated to extracorporal circulation.

In the present study, MB was employed to evaluated the hemodynamic and biochemical effects in a severe AP model in pigs. ${ }^{10,11}$

\section{Methods}

Surgical preparation of the animals. Thirty healthy male Dalland pigs weighing between 20 to $24 \mathrm{~kg}$ were studied at the Laboratory of Experimental Surgery, Department of Surgery and Anatomy, Faculdade de Medicina de Ribeirão Preto, University of São Paulo (FMRPUSP). The experimental model protocol and animal handling as well procedures were approved by the Committee of Ethics in Research of the FMRP-USP. Before the procedure all animals had a 12 hour fasting period except by water adlibitum.

The animals were anaesthetized with Midazolan (15 mg i.m. Cristália Chemical Products Ltda., Itapira, S.P., Brazil) and Tiletamine/Zolazepam (10 mg.kg-1 body weight - Telazol®, Fort Dodge, WI, USA) followed by a continuous i.v. infusion of Sulfentanil in the dose of $100 \mathrm{mg} . \mathrm{h}-1$ (Fastfan®, Cristália Chemical Products Ltda., Itapira, S.P., Brazil) and Propofol (10 mg.kg-1.h-1 Propovan®, Cristália Chemical Products Ltda., Itapira, S.P., Brazil) using a syringe pump (Syringe Infusion Pump, Harvard Apparatus, South Natick, Me, U.S.A.). Muscle relaxation was obtained with acid pancuronic (6 mg.h-1 Pancuron ${ }^{\circledR}$, Cristália Chemical Products Ltda., Itapira, S.P., Brazil). The animals received 3 $\mathrm{ml}$ of sodium chloride $0,9 \% . \mathrm{kg}-1$ body weight.h-1 i.v. to compensate insensitive losses. During the procedure the animals were kept in mechanic ventilation (Takaoka-
Model6000) with $\mathrm{FiO} 2$ of $40 \%$ and a intratracheal pressure of $8 \mathrm{mmHg}$. Venous access was obtained throughout the right jugular vein and a Swan-Ganz catheter (CCOmbo CCO/ SvO2 744HF75 Edwards Lifesciences, Irvine, CA, U.S.A) was introduced. Arterial access was obtained throughout the right femoral artery and a polyethylene catheter was introduced. The abdominal wall was opened by a midline incision extending about $15 \mathrm{~cm}$ from the xiphoid region. The duodenum as well the main pancreatic duct were identified. The main pancreatic duct was carefully isolated, opened and canalled using a catheter as described previously. ${ }^{11}$ The pancreatic catheter was exteriorized throughout the abdominal incision that was closed in a continuously fashion.

Data Collection. After surgical and anaesthetic procedures had been accomplishment including tracheostomy, venous and arterial access, hemodynamic monitoring, blood samples collection, main pancreatic duct cannulation, the animals were observed by a period of 45 minutes for hemodynamic stability. After this stability period, hemodynamic parameters were collected and registered continuously for 180 min using a MP System 100 (BioPacSystem, Incorporation, Santa Barbara, CA, U.S.A.). Arterial and venous blood samples were collected to biochemical analyses every $60 \mathrm{~min}$ from the beginning of the experiment (instant zero).

Experimental Protocol. Group Control (CTL) $(\mathrm{n}=6)$ : the animals received in sequence: a) $20 \mathrm{mLi}$.v. "bolus" of saline followed by saline maintenance ( $3 \mathrm{~mL} . \mathrm{kg}-1$ body weight.h-1 i.v.) b) continuous infusion of saline during the period of $1 \mathrm{~min}$ in the main pancreatic duct; Group MB $(n=6)$ : the animals received in sequence: a) MB solution i.v.; b) continuous infusion of saline during the period of $1 \mathrm{~min}$ in the main pancreatic duct; Group AP $(n=6)$ : the animals received in sequence: a) $20 \mathrm{mLi}$ i.v. "bolus" of saline followed by saline maintenance ( $3 \mathrm{~mL} . \mathrm{kg}-1$ body weight.h-1 i.v.) b) AP induction; Group MB plus AP $(n=6)$ : the animals received in sequence: MB solution i.v.; b) AP induction; Group AP plus MB ( $n=6)$ : the animals received in sequence: a) $20 \mathrm{~mL}$ i.v. "bolus" of saline followed by saline maintenance (3 mL.kg-1 body weight.h-1 i.v.) b) AP induction; c) after 90 minutes of AP induction, MB solution i.v..

AP induction. AP was induced immediately after basal parameters of hemodynamic, arterial and venous blood samples were collected. In brief, a continuous intraductal infusion of a $5 \%$ solution of sodium taurocholate (Sigma, St. Louis, Me, USA) in a dose of $1 \mathrm{ml} . \mathrm{kg}-1$ body weight with enterokinase (Sigma, St. Louis, Me, USA) in a dose of 8U.kg- 
1 body weight during a 1 minute period was performed as described also were. ${ }^{10,11}$

MB infusion. MB (Merck Diagnostica, Darmstadt, Germany) infusion was carried through an initial dose of $2 \mathrm{mg} . \mathrm{kg}-1$ body weight diluted in $20 \mathrm{ml}$ of $0,9 \%$ sodium chloride solution followed by a maintenance dose of 2 mg.kg-1 body weight.h-1 was done by a continuous intravenous infusion throughout the experiment.

Nitrate Dosage. Serum nitrate was indirectly measured by a Sievers NOAnalizer 280i using a NO/ozone chemioluminiscence technique. ${ }^{12}$

Malondialdehyde Dosage. MDA dosage was done using a Lipid Peroxidation Assay (Calbiochem San Diego, CA, U.S.A) as described previously. ${ }^{13}$

Biochemical Serum Analysis. Amilase, glicemia, creatinin, hematocrit, blood gas analyze were done using either a Stat Profile 9 Plus Analyzer (New Biomedical Co., ME, USA.) or a RapidLab 860 (Chiron Diagnostics Co.,Me, the U.S.A) or COULTER T-540 (Coulter Co., FL, U.S.A) or a Dimension device AIR (Dade Behring Incorporation, Deerfield, IL, U.S.A).

Pancreas Biopsy and Morphologic Study. At the end of data collection the previous laparotomy was extended from the xiphoid to the suprapubic region and the animals were sacrificed by exsanguination. The pancreas was identified, isolated and removed in all its extension. The pancreas was immediately fixed in a $10 \%$ formol solution, after which time the slides were prepared from paraffin blocks and stained with hematoxylin-eosin stain. Biopsy samples from all 30 animals were then examined blindly in order to eliminate observer bias. The slides were screened under light microscope for swelling, inflammatory infiltration, necrosis and hemorrhage.

\section{Statistical Analysis}

The results were expressed in arithmetic mean and standard deviation (sd). Serum amylase, glucose, creatinin and hematocrit were analyzed in 60 minutes intervals from time zero. Collected data were stored in a computer and plot in spread sheets of the Excel program (Microsoft, Seatle, WA, the U.S.A), and statistically analyzed using a Minitab 12.2.2 software (Minitab Incorporation, State College, PA, USA) and a S-Plus 3.3 software (Mathsoft Engineering \& Education Incorporation, Cambrigde, MA, U.S.A). The longitudinal comparisons were made by analysis of variance for repeated measures, and each instant for analysis of variance (ANOVA) with comparisons of Tukey, or Kruskal-
Wallis test, based on rank sum. Fisher's angular transformation was used to express results in percentage. $\mathrm{P}$ $<0.05$ were considered statistically significant.

\section{Results}

Hemodynamic results are summarized in Table 1. Figure 1 illustrate the continuously alterations in $\mathrm{CO}$ that occurred in all groups. MBP, CVP, PCP, CO, CI and $\mathrm{DO}_{2}$ decreased $(\mathrm{p}<0.05)$ over time in all AP groups. HR increased $(\mathrm{p}<.005)$ in all AP groups over time. SVR and PVR increased $(\mathrm{p}<0.05)$ in $\mathrm{AP}$ and $\mathrm{AP}+\mathrm{MB}$ groups. In $\mathrm{MB}+\mathrm{AP}$ group, there was a 70 minutes delay in the MBP and CO decrease $(\mathrm{p}<0.05)$ when compared to AP group. $\mathrm{DO}_{2}$ diminished in all AP groups although $\mathrm{MB}$ immediately before AP induction delayed $\mathrm{DO}_{2}$ decrease. $\mathrm{O}_{2} \mathrm{EI}$ increased $(\mathrm{p}<0.05)$ in all AP groups.

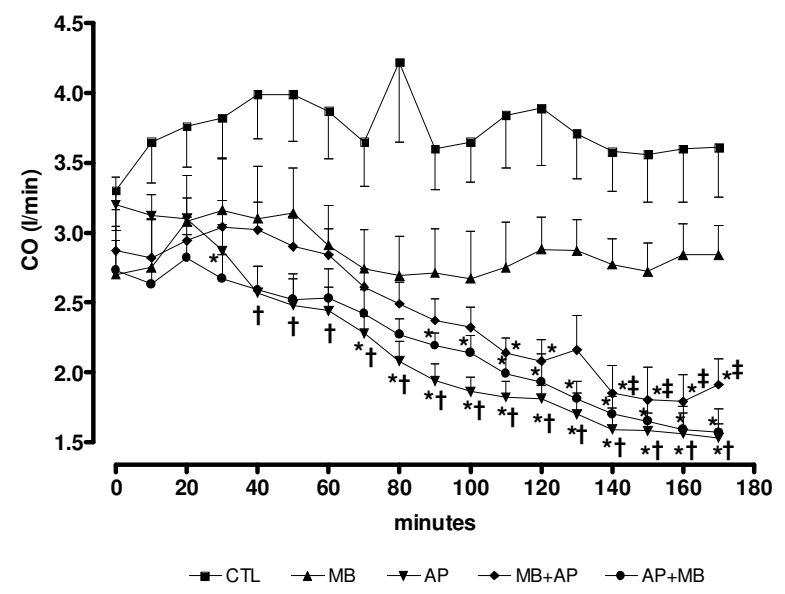

FIGURE 1 - Cardiac output (CO) results in all groups. In AP group CO decreased 52\% ( $\mathrm{p}<0.05)$ over time. In $\mathrm{MB}+\mathrm{AP}$ group, there was 70 minutes delay $(\mathrm{p}<0.05)$ to decrease $\mathrm{CO}$ compared to AP group. $\mathrm{MB}$ after AP induction did not improve $(\mathrm{p}<0.05) \mathrm{CO}$. CTL (control group), MB (methylene blue group), AP (acute pancreatitis group), MB (methylene blue group), $\mathrm{MB}+\mathrm{AP}$ (methylene blue plus acute pancreatitis group), AP+ MB (acute pancreatitis plus methylene blue group).

$* \mathrm{p}<0.05$ versus $\mathrm{t}(0)$

$\dagger \mathrm{p}<0.05$ CTL versus AP

$\ddagger \mathrm{p}<0.05 \mathrm{MB}$ versus $\mathrm{MB}+\mathrm{AP}$ 


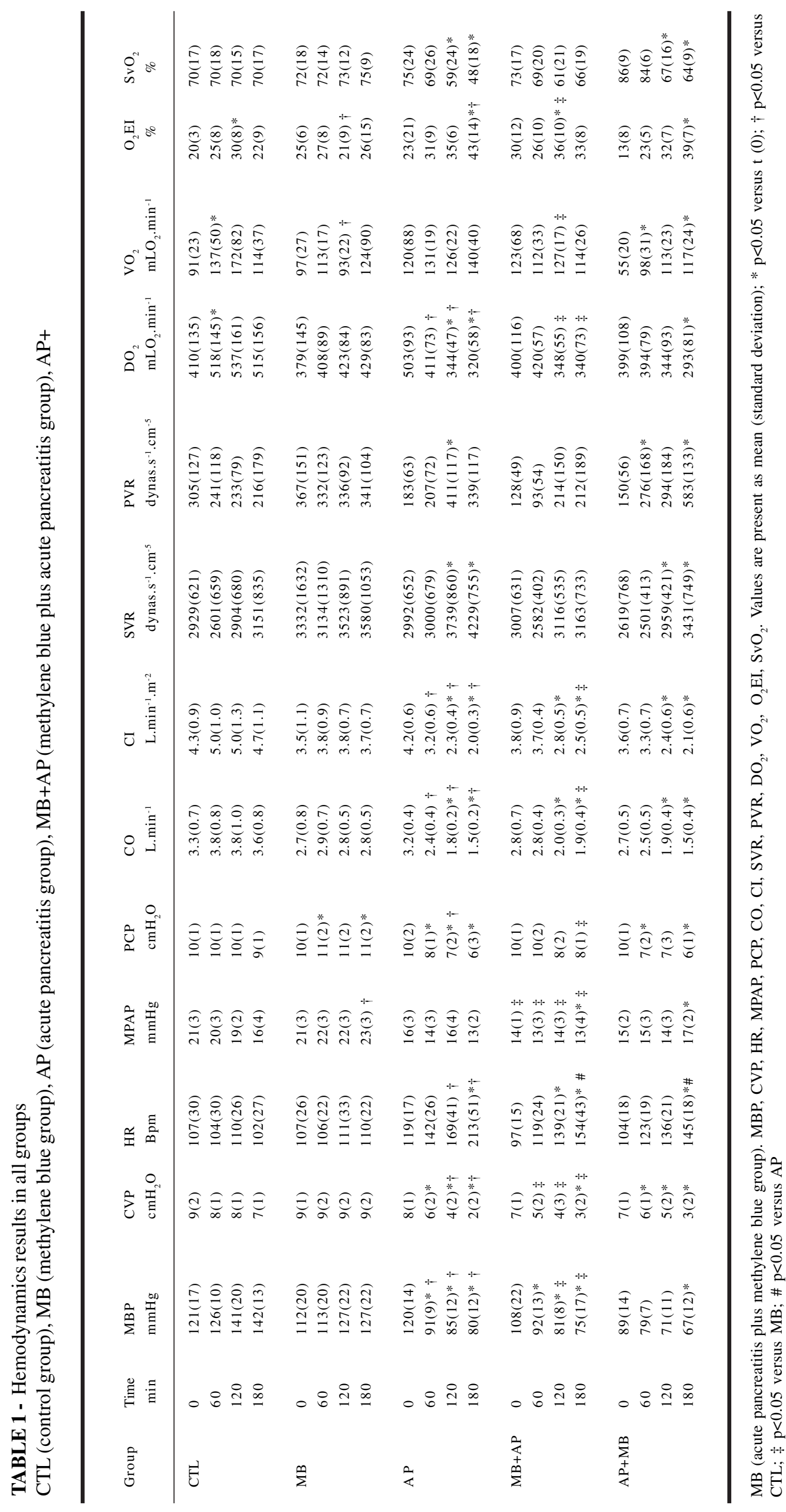


Table 2 shows the results of serum nitrate arterial and venous and amilase. Serum arterial nitrate decreased continuously $(\mathrm{p}<0.05)$ in MB group over time. Serum arterial nitrate increased $(\mathrm{p}<0.05)$ in both $\mathrm{AP}$ and $\mathrm{MB}+\mathrm{AP}$ groups when compared to CTL and MB groups at $180 \mathrm{~min}$, respectively.

Serum venous nitrate decreased $(\mathrm{p}<0.05)$ in $\mathrm{MB}$ group at $180 \mathrm{~min}$. In contrast, serum venous nitrate increased $(\mathrm{p}<0.05)$ in AP group at $180 \mathrm{~min}$. Serum venous nitrate increased $(\mathrm{p}<0.05)$ in both $\mathrm{AP}$ and $\mathrm{MB}+\mathrm{AP}$ groups when compared to CTL and MB groups at $180 \mathrm{~min}$, respectively. MDA increased $(\mathrm{p}<0.05)$ in MB group at $180 \mathrm{~min}$. In the $\mathrm{MB}+\mathrm{AP}$ group MDA increased $(\mathrm{p}<0.05)$ at 60, 120 and 180 min. In the $\mathrm{AP}+\mathrm{MB}$ group MDA increased $(\mathrm{p}<0.05)$ at 120 and 180 min. MDA in MB group was elevated $(\mathrm{p}<0.05)$ when compared to CTL group at $180 \mathrm{~min}$. MDA in MB+AP group were elevated $(\mathrm{p}<0.05)$ when compared to $\mathrm{MB}$ and $\mathrm{AP}$ groups at 60, 120 and $180 \mathrm{~min}$. It were also elevated $(\mathrm{p}<0.05)$ in $\mathrm{AP}+\mathrm{MB}$ group when compared to AP group at 120 and $180 \mathrm{~min}$. (Figure 2).

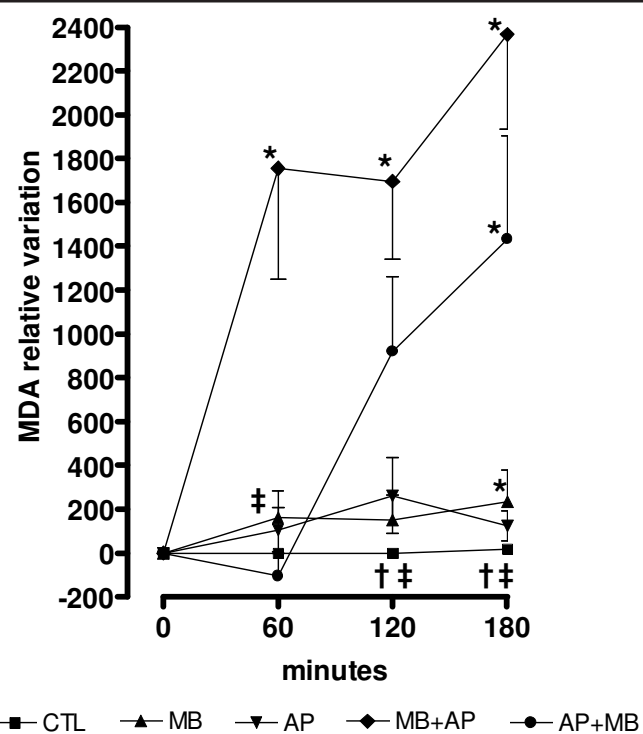

FIGURE 2 - Malondialdehyde (MDA) relative variation in all groups. CTL (control group), MB (methylene blue group), AP (acute pancreatitis group), MB (methylene blue group), MB+AP (methylene blue plus acute pancreatitis group), AP+ MB (acute pancreatitis plus methylene blue group). * $\mathrm{p}<0.05$ versus $\mathrm{t}(0) ; \dagger \mathrm{p}<0.05$ CTL versus $\mathrm{AP} ; \neq \mathrm{p}<0.05 \mathrm{AP}$ versus $\mathrm{AP}+\mathrm{MB} ; \# \mathrm{p}<0.05$ $\mathrm{MB}$ versus $\mathrm{MB}+\mathrm{AP}$

TABLE 2 - Serum arterial and venous nitrate and serum amylase results in all groups.

\begin{tabular}{|c|c|c|c|c|c|c|c|c|c|c|c|c|}
\hline \multirow[b]{2}{*}{ Time(min) } & \multicolumn{4}{|c|}{ Arterial Nitrate (mM) } & \multicolumn{4}{|c|}{ Venous Nitrate (mM) } & \multicolumn{4}{|c|}{ Amylase (UI.L ${ }^{-1}$ ) } \\
\hline & 0 & 60 & 120 & 180 & 0 & 60 & 120 & 180 & 0 & 60 & 120 & 180 \\
\hline CTL & $93(56)$ & $94(40)$ & $91(41)$ & $80(38)$ & $97(59)$ & $90(38)$ & $83(34)$ & $75(40)$ & $1507(656)$ & $1409(616)$ & $1388(625)$ & $1371(612)$ \\
\hline MB & $116(41)$ & $108(40)^{*}$ & $102(37)^{*}$ & $96(32) *+$ & $112(38)$ & $110(39)$ & 104(39) & $94(33)^{*} \ddagger$ & $1690(436)$ & $1576(419)$ & $1575(432)$ & $1552(434)$ \\
\hline AP & $99(22)$ & $99(31)$ & 104(31) & $116(33) \dagger$ & $97(21)$ & $97(31)$ & $102(32)$ & $114(39) * \dagger$ & $1714(257)$ & $2183(191)^{*} \dagger$ & $1679(1365)$ & $2166(1146)$ \\
\hline $\mathrm{MB}+\mathrm{AP}$ & $169(105)$ & 161(97) & $172(115)$ & $188(112)$ & $168(110)$ & $155(94)$ & $174(112)$ & 184(116) & $1210(466)$ & $2004(336)^{*}$ & $1758(1354)$ & $2728(822)^{*}$ \\
\hline $\mathbf{A P}+\mathbf{M B}$ & $94(11)$ & $92(10)$ & $98(17)$ & $105(20)$ & $93(7)$ & $93(14)$ & $96(18)$ & 101(15) & $1423(165)$ & $2231(1467)^{*}$ & $2483(2304)$ & $3757(199) *$ \\
\hline
\end{tabular}

CTL (control group), MB (methylene blue group), AP (acute pancreatitis group), MB+AP (methylene blue plus acute pancreatitis group), $\mathrm{AP}+\mathrm{MB}$ (acute pancreatitis plus methylene blue group). Values are present as mean (standard deviation). Values are present as mean (standard deviation).

* $\mathrm{p}<0.05$ versus $\mathrm{t}(0) ; \dagger \mathrm{p}<0.05$ versus $\mathrm{CTL} ; \ddagger \mathrm{p}<0.05 \mathrm{MB}$ versus $\mathrm{MB}+\mathrm{AP}$

TABLE 3 - Serum glucose, creatinine and hematocrit results in all groups.

\begin{tabular}{|c|c|c|c|c|c|c|c|c|c|c|c|c|}
\hline \multirow[b]{2}{*}{ Time(min) } & \multicolumn{4}{|c|}{ Glucose (mg.dL $\left.{ }^{-1}\right)$} & \multicolumn{4}{|c|}{$\operatorname{Cr}\left(\mathrm{mg.dL}^{-1}\right)$} & \multicolumn{4}{|c|}{ Ht (\%) } \\
\hline & 0 & 60 & 120 & 180 & 0 & 60 & 120 & 180 & 0 & 60 & 120 & 180 \\
\hline CTL & $108(15)$ & $100(18)$ & $93(13)$ & $93(8)$ & $0.9(0.1)$ & $0.9(0.1)$ & $0.9(0.1)$ & $0.9(0.1)$ & $30(2)$ & $28(2)$ & $28(3)$ & 29(3) \\
\hline MB & $108(30)$ & $76(22)$ & $70(26)^{*}$ & $63(28)^{*}$ & $1.1(0.2)$ & $1.1(0.2)$ & $1.1(0.2)$ & $1.1(0.2)$ & $32(2)$ & $30(2)$ & $31(2)$ & $31(2)$ \\
\hline AP & $120(19)^{*}$ & $72(14)$ & $64(22)$ & $58(12)^{*}$ & $0.8(0.1)$ & $0.8(0.1)$ & $1.0(0.1)$ & $1.1(0.1)^{*}$ & $35(3)$ & $37(3) \dagger$ & $42(2)^{*} \dagger$ & $46(2)^{*} \dagger$ \\
\hline $\mathrm{MB}+\mathrm{AP}$ & $124(29)^{*}$ & $59(17)$ & $55(11)^{*}$ & $51(18)^{*}$ & $0.9(0.1)$ & $1.0(0.2)$ & $1.1(0.2)$ & $1.2(0.2)^{*}$ & $32(1)$ & $34(1)$ & $38(2)^{*}$ & $41(3)^{*}$ \\
\hline $\mathrm{AP}+\mathrm{MB}$ & $138(49)^{*}$ & $60(12)$ & $64(26)$ & $61(26)^{*}$ & $0.9(0.1)$ & $0.8(0.1)$ & $1.1(0.1) \ddagger$ & $1.3(0.1)^{*}$ & $34(3)$ & $35(2) \#$ & $39(2)^{*} \#$ & $40(1)^{*} \#$ \\
\hline
\end{tabular}

CTL (control group), MB (methylene blue group), $\mathrm{AP}$ (acute pancreatitis group), $\mathrm{MB}+\mathrm{AP}$ (methylene blue plus acute pancreatitis group), $\mathrm{AP}+$

MB (acute pancreatitis plus methylene blue group). Values are present as mean (standard deviation).

$* \mathrm{p}<0.05$ versus $\mathrm{t}(0) ; \dagger \mathrm{p}<0.05$ versus $\mathrm{CTL} ; \ddagger \mathrm{p}<0.05$ AP versus $\mathrm{AP}+\mathrm{MB} ; \# \mathrm{p}<0.05 \mathrm{MB}$ versus $\mathrm{MB}+\mathrm{AP}$ 
Serum amylase levels were elevated $(\mathrm{p}<0.05)$ in AP group at $60 \mathrm{~min}$. Serum amylase levels were elevated $(\mathrm{p}<0.05)$ in $\mathrm{MB}+\mathrm{AP}$ and $\mathrm{AP}+\mathrm{MB}$ groups at 60 and $180 \mathrm{~min}$. There was increased $(\mathrm{p}<0.05)$ serum amylase when compared CTL group to AP group at $60 \mathrm{~min}$.

Serum glucose, creatinin and hematocrit results are showed in Table 3. Serum glucose levels decreased $(\mathrm{p}<0.05)$ in MB group at 120 and $180 \mathrm{~min}$; in MB+AP group at 60, 120 and $180 \mathrm{~min}$; in $\mathrm{AP}$ and $\mathrm{AP}+\mathrm{MB}$ groups at 60 and $180 \mathrm{~min}$. No difference $(\mathrm{p}>0.05)$ were seen among groups.

Creatinin serum levels increased $(\mathrm{p}<0.05)$ in all AP groups $\mathrm{AP}$ at $180 \mathrm{~min}$, moreover in $\mathrm{AP}+\mathrm{MB}$ group that increased $(p<0.05)$ at $120 \mathrm{~min}$. Creatinin serum levels were elevated $(\mathrm{p}<0.05)$ in $\mathrm{MB}+\mathrm{AP}$ group when compared to AP group at $180 \mathrm{~min}$.

Hematocrit increased $(\mathrm{p}<0.05)$ in all AP groups. At the end of the experiment, there were a mean increase of 32 , 26 , and $20 \%$ in $\mathrm{AP}, \mathrm{MB}+\mathrm{AP}$ and $\mathrm{AP}+\mathrm{MB}$ groups, respectively.

Pancreatic morphological study from CTL and MB groups showed normal gland. However, pancreas from all AP groups presented with bright dark reddish surface with black spots, swelled and jelly consistence. Microscopy study in CTL and MB groups was unremarkable but it revealed necrosis and hemorrhage in all AP groups. None leukocytes infiltration was seen.

\section{Discussion}

MB has been used as a therapeutic drug for more than 110 years ${ }^{14}$ mainly for methemoglobinemia treatment, cyanate antidote and fistula localization. ${ }^{15}$ In AP group, venous nitrate levels increased over time and arterial nitrate levels were higher when compared with group CTL. This increase was associated with hypotension, CO and PCP decrease and hemoconcentration. In severe AP, inducible nitric oxide synthase (iNOS) overproduces NO. Excessive NO production cause pathological vasodilatation with capillary permeability increase and third space fluid loss ${ }^{16}$ and tissue injury by NO derived free-radicals overproduction. AL MUFTI et al. (1998) demonstrated an increase in iNOS activity associated to systemic NO increase and arterial hypotension in AP experimental models. ${ }^{17,18}$ Thus, inhibition of iNOS may have a potential benefic effect in a variety of pathophysiologic alterations in AP.

The findings of MBP, CVP, CO and CI reduction in AP group associated to HR, SVR and PVR increase with hemoconcentration confirm the method reproducibility regarding precocious hypovolemic shock manifestations in this AP experimental model. ${ }^{19} \mathrm{CO}$ and $\mathrm{CI}$ reduction during AP induction is primarily related to hypovolemia and due to preload reduction. ${ }^{20}$ Experimental studies had demonstrated that MBP decrease correspond to 26 to $45 \%$ circulating volume decrease $\mathrm{e}^{21,22}$ In this study it was $32 \%$ in AP group.

Our objective was to evaluate initial AP treatment with MB without volemic replacement. When compared AP groups there was a delay in $\mathrm{CO}$ and $\mathrm{CI}$ reduction in $\mathrm{MB}+\mathrm{AP}$ group although there were no difference at the end of the experiment. In AP group it initiated at 70 minutes and only at 140 minutes in $\mathrm{MB}+\mathrm{AP}$ group. However, MB given 90 minutes after AP induction, did not revert the hemodynamic changes. When there is volemic replacement, $\mathrm{CO}$ and $\mathrm{CI}$ do not decrease in severe AP initial phase and hemoconcentration precedes hemodynamic alteration ${ }^{23}$ Hemoconcentration was present 10 minutes before $\mathrm{CO}$ and $\mathrm{CI}$ decrease in AP group. Furthermore, in $\mathrm{MB}+\mathrm{AP}$ group occurred hemoconcentration at least 50 minutes before $\mathrm{CO}$ and CI decrease. We observed that $\mathrm{MB}$ (dose of $2 \mathrm{mg} . \mathrm{kg}^{-1} \cdot \mathrm{h}^{-}$ ${ }^{1}$ ) increased PVR, that also was reported in shock septic patients treated with MB $\left(4 \mathrm{mg} \cdot \mathrm{kg}^{-1} \cdot \mathrm{h}^{-1}\right)^{24} \mathrm{MB}$ inhibition on NO vasodilatation and prostaglandins action may explain PVR increase in septic shock and inflammatory conditions where both action are increased ${ }^{25}$ differently from normal physiological conditions as seen in MB group.

$\mathrm{DO}_{2}$ diminished in AP groups although $\mathrm{MB}$ immediately before AP induction delayed $\mathrm{DO}_{2}$ decrease, most probably related to $\mathrm{CO}$ decrease. $\mathrm{O}_{2} \mathrm{EI}$ increase observed in AP groups reflects AP hypovolemic condition and it suggests a compensation attempt due to $\mathrm{DO}_{2}$ decrease and $\mathrm{VO}_{2}$ increase. ${ }^{26}$ However, AP patients that had volemic correction with crystalloid solutions present $\mathrm{DO}_{2}$ and $\mathrm{VO}_{2}$ increase suggesting that AP increases metabolic demand. ${ }^{26}$

Serum nitrate levels increase was not observed when MB was used either before or after AP induction. An unexpected reduction of arterial and venous serum nitrate levels were observed suggesting inhibition of NO effect independent of GMPc inhibition ${ }^{27}$. However, this effect seems partial because $\mathrm{MB}$ did not decrease serum nitrate levels in the $\mathrm{MB}+\mathrm{AP}$ or $\mathrm{AP}+\mathrm{MB}$ groups. This mechanism can be due to the production of superoxide, a NO inactivator. Oxidatio of the reduced form of MB induces the generation of this free radical $^{27,28}$, justifying the findings of MDA increases associated to MB infusion".

Free radicals (FR) generation seems to be involved in AP experimental models correlated to ischemia, alcohol and biliary etiology. ${ }^{29,30}$ However, MDA serum levels did not increased in AP group. Different experimental models of AP seem to present different degrees and mechanisms of FR formation, with lesser impact in taurocholate-induced AP. ${ }^{30}$ Adversely, MB promoted increase of MDA serum levels with a significant impact when it was associated with AP. There are evidence that L-NAME induces the RL production $^{31,32}$. MARCZIN et al. ${ }^{33}$ had demonstrated that, in physiological conditions, MB inactives NO with consequent increase in superoxide concentration and lipoperoxidation. ${ }^{34}$ Therefore, it seems that MDA serum increase in group $\mathrm{MB}$ corresponds probably to $\mathrm{NO}$ inactivation with consequent NO physiological actions blockage. MDA levels increase, associated with the use of MB during AP, seems not to be associated to initial NO production by iNOS. The NO release, in great amounts, demand necessary time since the initial stimulation to its final production that involves cellular enzymatic mechanisms. The NO increase occurred 180 min after AP induction.

NO may be a cytotoxic mediator during taurocholate-induced $\mathrm{AP}^{3}$ In fact, NO cytotoxicity is 
attributed to its reaction with ion superoxide forming peroxynitrite. ${ }^{35,36}$ Although peroxynitrite production precedes iNOS expression, there was no MDA increase in AP group.

Initial studies in sepsis had shown that NO overproduction is responsible by hypotension and that iNOS blockage improves it without improving mortality. ${ }^{37-39}$ The reason is due to no selective iNOS inhibitors, that NO blocking interferes with perfusion regulation, capillary permeability and leukocytes/platelets interactions. A possible explanation for these findings may be that $\mathrm{NO}$ blockage by MB improved systemic hemodynamic parameters during AP, although in the cellular level it promoted a poor tissue perfusion due to its vasoconstrictor action. Moreover, MB increases platelets activity in hypovolemic and hemoconcentration conditions propitiating lipoperoxidation and tissue perfusion aggravation. Serum amylase levels increase, MB+AP and $\mathrm{AP}+\mathrm{MB}$ groups, may correspond to suppression of $\mathrm{NO}$ beneficial effect in pancreatic microcirculation. NO is a mediator that increases pancreatic blood flow in response to physiological stimulation of CCK and secretin. ${ }^{40} \mathrm{NO}$ may confer protection against AP development, probably due to pancreatic microcirculation improvement and leukocytes adhesion reduction..$^{41-43}$

Serum creatinin increase in AP groups is in accordance with LEVY et al. ${ }^{44}$ that demonstrated acute renal insufficiency consequence to hypovolemia in taurocholateinduced AP model. Serum creatinin worsening in AP+MB group confirms $\mathrm{MB}$ vasoconstrictor effect on renal circulation thus aggravating a vasoconstriction due to hypovolemia.

Hypoglycemia occurred in all groups except in group CTL. Hypoglycemia in AP groups may be explained by cells beta destruction and insulin release during taurocholate-induction AP. On the other hand, MB group also presented hypoglycemia over time probably due to a blockage of an insulin inhibitory secretion mechanism NO dependent. ${ }^{45,46}$ There was no improvement in necrohemorrhagic findings with MB treatment.

In this taurocholate-induced AP model we concluded that MB treatment delayed hemodynamic shock and decreases serum nitrate levels but increases serum MDA levels. In our experiment, no volemic replacement was done and it may have been a mitigated factor to a poor tissue perfusion and impairment microcirculation. Further investigations are needed to elucidate $\mathrm{MB}$ treatment role during AP treatment.

\section{References}

1. Sweiry JH, Mann GE. Role of oxidative stress in the pathogenesis of acute pancreatitis. Scand J Gastroenterol Supp.1 1996;219:10-5.

2. Tani S, Itoh H, Okabayashi Y, Nakamura T, Fujii M, Fujisawa T, Koide M, Otsuki M. New model of acute necrotizing pancreatitis induced by excessive doses of arginine in rats. Dig Dis Sci. 1990;35:367-74.
3. Dabrowski A, Gabryelewicz A. Nitric oxide contributes to multiorgan oxidative stress in acute experimental pancreatitis. Scand J Gastroenterol. 1994;29:943-8.

4. Gukovskaya A, Pandol S. Nitric oxide production regulates cGMP formation and calcium influx in pancreatic acinar cells. Am J Physiol. 1994;266:G3506.

5. Holst JJ, Rasmussen TN, Schmidt P. Role of nitric oxide in neurally induced pancreatic exocrine secretion in pigs. Am J Physiol. 1994;266:G206-13.

6. Satoh A, Shimosegawa T, Abe T, Kikuchi Y, Abe R, Koizumi M, Toyota T. Role of nitric oxide in the pancreatic blood flow response to caerulein. Pancreas. 1994;9:574-9.

7. Patel AG, Toyama MT, Nguyen TN, Cohen GA, Ignarro LJ, Reber HA, Ashley SW. Role of nitric oxide in the relationship of pancreatic blood flow and exocrine secretion in cats. Gastroenterology. 1995;108:1215-20.

8. Holzmann S. Endothelium-induced relaxation by acetylcholine associated with larger rises in cyclic GMP in coronary arterial strips. J Cyclic Nucleotide Res. 1982;8:409-19.

9. Martin W, Villani GM, Jothianandan D, Furchgott RF. Selective blockade of endothelium-dependent and glyceryl trinitrate-induced relaxation by hemoglobin and by methylene blue in the rabbit aorta. J Pharmacol Exp Ther. 1985;232:708-16.

10. Aho HJ, Koskensalo SM, Nevalainen TJ. Experimental pancreatitis in the rat. Sodium taurocholate-induced acute haemorrhagic pancreatitis. Scand J Gastroenterol. 1980;15:411-6.

11. Yekebas EF, Treede H, Knoefel WT, Bloechle C, Fink E, Izbicki JR. Influence of zero-balanced hemofiltration on the course of severe experimental pancreatitis in pigs. Ann Surg. 1999;229:514-2.

12. Antunes-Rodrigues J, McCann SM. Water, sodium chloride, and food intake induced by injections of cholinergic and adrenergic drugs into the third ventricle of the rat brain. Proc Soc Exp Biol Med. 1970;133:146470.

13. Buege JA, Aust SD. Microsomal lipid peroxidation. Methods Enzymol. 1978;52:302-10.

14. Wainwright M, Crossley KB. Methylene Blue-a therapeutic dye for all seasons? J Chemother. 2002;14:431-43.

15. Blass N, Fung D. Dyed but not dead-methylene blue overdose. Anesthesiology. 1976;45:458-9.

16. Simsek I, Mas MR, Yasar M, Ozyurt M, Saglamkaya U, Deveci S, Comert B, Basustaoglu A, Kocabalkan F, Refik M. Inhibition of inducible nitric oxide synthase reduces bacterial translocation in a rat model of acute pancreatitis. Pancreas. 2001;23:296-301.

17. Morikawa M, Inoue M, Tokumaru S, Kogo H. Enhancing and inhibitory effects of nitric oxide on superoxide anion generation in human polymorphonuclear leukocytes. Br J Pharmacol. 1995;115:1302-6.

18. Al-Mufti RA, Williamson RC, Mathie RT. Increased nitric oxide activity in a rat model of acute pancreatitis. Gut. 1998;43:564-70. 
19. Steinberg SM, Gower WR Jr, Martin D, Carey LC, Cloutier CT. Experimental pancreatitis does not produce pulmonary hypertension. Surg Gynecol Obstet. 1983;157:530-3.

20. Rämä OJ, Rämö P, Karhunen M, Kiviniemi H, Kettunen $\mathrm{R}$. Impaired venous return causes circulatory failure in experimental pancreatitic shock in dogs. Intensive Care Med. 1989;15:111-5.

21. Anderson MC, Schoenfeld FB, Iams WB, Suwa M. Circulatory changes in acute pancreatitis. Surg Clin North Am. 1967;47:127-40.

22. Wulff K, Sjostrom B. Influence of acute pancreatitis on central hemodynamic, regional blood flow distribution and arteriovenous shunting in the dog. Eur Surg Res. 1974;6:354-63.

23. Kinnala PJ, Kuttila KT, Grönroos JM, Havia TV, Nevalainen TJ, Niinikoski J. Central haemodynamics in experimental acute pancreatitis. Eur J Surg. 1999;165:598-603.

24. Weingartner R, Oliveira E, Oliveira ES, Sant' Anna UL, Oliveira RP, Azambuja LA, Friedman G. Blockade of the action of nitric oxide in human septic shock increases systemic vascular resistance and has detrimental effects on pulmonary function after a short infusion of methylene blue. Braz J Med Biol Res. 1999;32:1505-13.

25. Wheeler AP, Bernard GR. Treating patients with severe sepsis. N Engl J Med. 1999;340:207-14.

26. Cobo JC, Abraham E, Bland RD, Shoemaker WC. Sequential hemodynamic and oxygen transport abnormalities in patients with acute pancreatitis. Surgery. 1984;95:324-30.

27. Keaney JF Jr, Puyana JC, Francis S, Loscalzo JF, Stamler JS, Loscalzo J. Methylene blue reverses endotoxininduced hypotension. Circ Res. 1994;74:1121-5.

28. Mayer B, Brunner F, Schmidt K. Inhibition of nitric oxide synthesis by methylene blue. Biochem Pharmacol. 1993;45:367-74.

29. Sanfey H, Sarr MG, Bulkley GB, Cameron JL. Oxygenderived free radicals and acute pancreatitis: a review. Acta Physiol Scand Suppl. 1986;548:109-18.

30. Niederau C, Niederau M, Borchard F, Ude K, Lüthen R, Strohmeyer G, Ferrell LD, Grendell JH. Effects of antioxidants and free radical scavengers in three different models of acute pancreatitis. Pancreas. 1992;7:486-96.

31. Suematsu M, Tamatani T, Delano FA, Miyasaka M, Forrest M, Suzuki H, Schmid-Schönbein GW. Microvascular oxidative stress preceding leukocyte activation elicited by in vivo nitric oxide suppression. Am J Physiol. 1994;266:H2410-5.

32. Kurose I, Wolf R, Grisham MB, Aw TY, Specian RD, Granger DN. Microvascular responses to inhibition of nitric oxide production. Role of active oxidants. Circ Res. 1995;76:30-9.

33. Marczin N, Ryan US, Catravas JD. Methylene blue inhibits nitrovasodilator- and endothelium-derived relaxing factor-induced cyclic GMP accumulation in cultured pulmonary arterial smooth muscle cells via generation of superoxide anion. J Pharmacol Exp Ther. 1992;263:170-9.

34. Rubanyi GM, Vanhoutte PM. Superoxide anions and hyperoxia inactivate endothelium-derived relaxing factor. Am J Physiol. 1986;250:H822-7.

35. Beckman JS, Beckman TW, Chen J, Marshall PA, Freeman BA. Apparent hydroxyl radical production by peroxynitrite: implications for endothelial injury from nitric oxide and superoxide. Proc Natl Acad Sci U S A. 1990;87:1620-4.

36. Viola G, al-Mufti RA, Sohail M, Williamson RC, Mathie RT. Nitric oxide induction in a rat model of selective pancreatic ischemia and reperfusion. Hepatogastroenterology. 2000;47:1250-5.

37. Kilbourn RG, Jubran A, Gross SS, Griffith OW, Levi R, Adams J, Lodato RF. Reversal of endotoxin-mediated shock by NG-methyl-L-arginine, an inhibitor of nitric oxide synthesis. Biochem Biophys Res Commun. 1990;172:1132-8.

38. Petros A, Lamb G, Leone A, Moncada S, Bennett D, Vallance P. Effects of a nitric oxide synthase inhibitor in humans with septic shock. Cardiovasc Res. 1994;28:34-9.

39. Nava E, Palmer RM, Moncada S. Inhibition of nitric oxide synthesis in septic shock: how much is beneficial? Lancet. 1991;338:1555-7.

40. Konturek SJ, Bilski J, Konturek PK, Cieszkowski M, Pawlik W. Role of endogenous nitric oxide in the control of canine pancreatic secretion and blood flow. Gastroenterology. 1993;104:896-902.

41. Liu X, Nakano I, Yamaguchi H, Ito T, Goto M, Koyanagi $\mathrm{S}$, Kinjoh M, Nawata H. Protective effect of nitric oxide on development of acute pancreatitis in rats. Dig Dis Sci. 1995;40:2162-9.

42. Werner J, Rivera J, Fernandez-del Castillo C, Lewandrowski K, Adrie C, Rattner DW, Warshaw AL. Differing roles of nitric oxide in the pathogenesis of acute edematous versus necrotizing pancreatitis. Surgery. 1997;121:23-30.

43. Werner J, Fernández-del Castillo C, Rivera JA, Kollias N, Lewandrowski KB, Rattner DW, Warshaw AL. On the protective mechanisms of nitric oxide in acute pancreatitis. Gut. 1998;43:401-7.

44. Levy M, Geller R, Hymovitch S. Renal failure in dogs with experimental acute pancreatitis: role of hypovolemia. Am J Physiol. 1986;251:F969-77.

45. Southern C, Schulster D, Green IC. Inhibition of insulin secretion by interleukin-1 beta and tumour necrosis factor-alpha via an L-arginine-dependent nitric oxide generating mechanism. FEBS Lett. 1990;276:42-4.

46. Kolb H, Kolb-Bachofen V. Type 1 (insulin-dependent) diabetes mellitus and nitric oxide. Diabetologia. 1992;35:796-7. 
Acknowledgements:

FAPESP and FAEPA

\section{Correspondence :}

Roberto Ferreira Meirelles Jr.

Disciplina de Transplante e Cirurgia do Fígado

São Paulo Faculty of Medicine, Department of Surgery

Universidade of São Paulo.

Conflict of interest: none

Av. Dr.Arnaldo, 455, $3^{\circ}$ andar, sala 6.

Financial Source: FAPESP and FAEPA

CEP: 01246-903 São Paulo, Brazil.

Phone/Fax: 55-11-30667270.

roberto.meirelles@hcnet.usp.br

\section{How to cite this article:}

Meirelles Jr RF, Ceneviva R, Viaro F, Evora PRB. Methylene blue improves hemodynamic shock but increases lipoperoxidation in severe acute pancreatitis pig model. Acta Cir Bras [serial on the Internet] 2008; 23 Suppl 1. Available from URL: http://www.scielo.br/acb.

\section{Comments:}

Current literature data indicates that methylene blue may reverse or ameliorate hemodynamic alterations caused by the systemic inflammatory syndrome through blockage of nitric oxide activity. Nitric oxide is a vasodilator and regulates the exocrine and endocrine (insulin) pancreatic secretion and the microvascular blood flow. The use of NO in acute experimental pancreatitis shows controversial results. Some studies (Werner et al., 1997; Molero et al., 1995) suggest a protective effect probably due to increased blood flow in the pancreatic micro circulation. Waindebach et al. (1995) did not observe any effect of NO in acute pancreatitis, but others (Dabrowiski et al.,1994; Iomis et al., 1995) had evidence of an injurious effect, thought to be due to oxidative stress, vasodilatation and tissue hypoperfusion. In this study, Meirelles et al. proposed the study of hemodynamic profiles and lipid peroxidation in pigs with acute pancreatitis induced by taurocholate enterokinase, and submitted to treatment with methylene blue, as a NO inhibitor, before and after pancreatitis induction. The dye was able to reduce serum nitrate levels, but lipid peroxidation was increased as shown by serum levels of malon dialdehyde. The results in the study warrant the conclusion that the use of methylene blue before induction of severe acute experimental pancreatitis offered a transitory protection to hemodynamic shock. However, there was a deleterious effect on lipid peroxidation and the claim that there is an improvement in circulatory shock by the use of methylene blue should be avoided.

\section{Rafael Kemp}

MD, Assistant, Division of Digestive Surgery, Department of Surgery and Anatomy, Ribeirão Preto Faculty of Medicine, University of São Paulo, Brazil

\section{José Sebastião dos Santos}

PhD, Professor, Division of Digestive Surgery, Department of Surgery and Anatomy, Ribeirão Preto Faculty of Medicine, University of São Paulo, Brazil. 